\title{
Long-term energy supply contracts in European competition policy: Fuzzy not crazy
}

\author{
Adrien de Hauteclocque ${ }^{\mathrm{a}, *}$, Jean-Michel Glachant ${ }^{\mathrm{b}}$ \\ ${ }^{a}$ University of Manchester School of Law, Oxford Road, Manchester M13 9PL, UK \\ ${ }^{\mathrm{b}}$ European University Institute RSCAS and Florence School of Regulation, 19 Via delle Fontanelle, 50014 San Domenico di Fiesole, Italy
}

\section{A R T I C L E I N F O}

\section{Article history:}

Received 12 February 2009

Accepted 31 July 2009

\section{Keywords:}

Long-term contracts

Competition policy

European union

\begin{abstract}
A B S T R A C T
Long-term supply contracts often have ambiguous effects on the competitive structure, investment and consumer welfare in the long term. In the new market context, these effects are likely to be worsened and thus even harder to assess. Since liberalization and especially since the release of the Energy Sector Inquiry in early 2007, the portfolio of long-term supply contracts of the former incumbents have become a priority for review by the European Commission and the national competition authorities. It is widely believed that European Competition authorities take a dogmatic view on these contracts and systemically emphasize the risk of foreclosure over their positive effects on investment and operation. This paper depicts the methodology that has emerged in the recent line of cases and argues that this interpretation is largely misguided. It shows that a multiple-step approach is used to reduce regulation costs and balance anti-competitive effects with potential efficiency gains. However, if an economic approach is now clearly implemented, competition policy is constrained by the procedural aspect of the legal process and the remedies imposed remain open for discussion.
\end{abstract}

(C) 2009 Elsevier Ltd. All rights reserved.

\section{Introduction}

Long-term supply contracts (LTC) remain a pervasive feature of most European energy markets despite the progress of liberalization (DG COMP, 2007). To get out of the monopoly era, the current refining and harmonization of European market designs may be pointless if incumbents continue to use these contracts as devices to control market (Glachant and Lévêque, 2009; Neumann and von Hirschhausen, 2006). These contracts indeed frequently have anti-competitive foreclosure effects when competition is imperfect (Fumagalli and Motta, 2006; Rasmusen et al., 1991; Segal and Whinston, 2000) and these effects are likely to be worsened in the new market context. However, there is growing acceptance that their positive impact on investment makes them desirable as long as spot market competition remains unsatisfactory (Chao et al., 2008; Finon and Roques, 2008). Welfareenhancing aspects must thus be weighed against possible side effects on the current efforts of the European Union (EU) to create truly competitive markets.

Today, the allocation of regulatory powers in the EU is biased in favor of the ex post enforcement of EC antitrust law. The institutional structure of the European Union does not give to the European Commission the power to alter property rights in

\footnotetext{
* Corresponding author. Tel.: +33637427175; fax: +33140916427.

E-mail address: adehauteclocque@hotmail.com (A.d. Hauteclocque).
}

the different member states and thus to carry an aggressive policy of horizontal de-integration which would probably deliver better and faster results (Green and Newbery, 1997; Newbery et al., 2003). In addition, the lack of an EU-wide energy regulator with effective power to monitor and regulate market developments, especially cross-border trade issues, is particularly detrimental to the integration and the well-functioning of European energy markets (Glachant and Lévêque, 2009). While sector-specific regulation shows obvious signs of weakness, the European Commission has announced it would use its antitrust power with even more strength in the coming years (DG COMP 2007; Monti, 2003).

Conducting market building through antitrust does not go without uncertainties about the suitability of the policy tool itself and about the ability of the judges to enforce it. Antitrust policy remains constrained by the legal process, and especially judicial review. This also raises questions both about the discretion which a process of market building requires to be conducted efficiently and about the time and cost of dispute resolution through court trial (Newbery, 2006). In addition, the antitrust laws are usually enforced in sectors where competition is more mature and a limited knowledge of competition dynamics may result in significant error costs (Smeers, 2009).

Following a worldwide trend in global antitrust (Van den Bergh, 2002), the on-going modernization of EC antitrust policy aims at implementing a 'more economic' approach based on long-term consumer welfare. It means gradually shifting from a 
legal 'form-based' analysis of contracts to a more 'effect-based' approach where the real economic effects of competitive behaviors are more important than the drafting of contracts (Ehlermann, 2000; Gual et al., 2005; Verouden, 2003; Wesseling, 2000). The 'more economic' approach might significantly impact the way the EC antitrust laws are enforced, which brings new uncertainties both for the regulator and the regulated firms.

If EC antitrust policy becomes one of the main energy policy tool at the EU level to open markets, it is worth analyzing the forces which shape its implementation. The case of LTC is particularly interesting as they have become one of the main priorities for antitrust enforcement (DG COMP, 2007). A series of cases has already been published and new ones are regularly opened, for instance lately against EDF and Electrabel. A widespread view, both in academia and in the industry, is that the European Commission is taking a dogmatic view on LTC and would simply consider them unacceptable when implemented by dominant companies. This can be understood as DG Competition since the early 2000s has publicly and repeatedly voiced strong concerns over the risks of anti-competitive effects inherent in energy LTC (Albers, 2001-2002; DG COMP, 2007). However, a more economic approach in antitrust could not reject outright LTC in energy and should command a more balanced approach.

The objective of this paper is two-fold. The first one is to depict the pros and cons of LTC in energy, from the usual IO and NIE perspectives (e.g. Neuhoff and von Hirschhausen, 2006), which are the perspectives of individual contracting parties, as well as from a general antitrust point of view. The second one is to analyze the actual behavior of the European Commission vis-à-vis these contracts and the methodology it is implementing to analyze foreclosure in the existing context.

The paper will be divided as follows. Section 2 will present what economics has to say on the current EU antitrust dilemma with LTC in energy and what are its limitations. Section 3 will depict the two-step methodology that is emerging at the European Commission to analyze the anti-competitive effects of energy LTC. Section 4 will then turn to the difficulties which the European Commission has to balance the anti-competitive effects and the potential efficiency gains. It will also analyze the remedies imposed to correct the anti-competitive features of European energy markets and the 'pro-entry' bias that can be depicted. Concluding remarks will follow.

\section{The EU actual antitrust dilemma with LTC in energy: foreclosure vs. transaction costs}

In essence, antitrust policy is about maximizing long term social welfare, with a general bias in favor of consumer welfare in the EU. This often implies constraining the freedom of some economic agents in the short term to reach a greater social value over several periods of times. It is typically the case with the deregulation of energy markets where incumbents may have to suffer some harm to facilitate the emergence of truly competitive markets, deemed to increase social welfare through better generation performance, labor productivity, service quality in distribution and network congestion management (Newbery and Pollitt, 1997; Markiewicz et al., 2004). The balancing between the efficiency gains of long-term contracting for a few individual market players and the potential negative effects on social welfare are at the hearth of the antitrust dilemma with LTC in energy. However, restricting the freedom to contract of some agents must be based on valid economic reasoning and requires being able to conduct some kind of inter-temporal analysis of the effects of LTC on welfare. We present in this section a basic economic analysis of the pros and cons of LTC for individual market players and for the society as a whole.

\subsection{LTC decrease transaction costs for contracting parties}

LTC are often considered an efficient substitute for vertical integration in case merger is prohibited or considered to incur too heavy organizational costs. The main advantage of LTC for individual firms is to hedge price and quantity risks and therefore facilitate investment or operation. In the old monopoly era, vertical integration and long-term contracting were the preferred way to structure business relationships in energy. Reliability and investment were ensured, but at a hidden cost for society (Stern, 2004; Littlechild, 2005). In the new competitive paradigm, large and stable spot markets are to coordinate behaviors and should be liquid enough to enable firms to sink high fixed costs investments based on reliable investment signals. Yet, European spot markets remain under-developed (DG COMP, 2007), demand is inelastic and market structures are highly concentrated, hence firms tend to resort to more durable vertical arrangements. If spot markets are under-developed, future cash flows are uncertain and the uncertainty on the returns will lead risk-averse investors to under-invest in generation capacities (Neuhoff and de Vries, 2004). LTC may mitigate this by providing an insurance device which will also help secure funds with investment banks under project financing structures (Finon and Roques, 2008; Lacy, 2006). However, it is not clear whether short term cash management rationale should extend to pure long-term hedging strategies not linked to any new investment in capacity. Indeed, long-term hedging of a substantial part of output would severely limit profit opportunities in the case of already amortized power plants (Parsons, 2008).

If bilateral contracting is unavoidable due to the state of spot market development, LTC will help economize on the transaction costs (Williamson, 1975, 1985) linked to the uncertainty of the ongoing process of liberalization and the significant asset specificity of investments in energy markets. In this line of reasoning, LTC are thought to help contracting parties solve the problems of counterparty credibility and opportunistic behavior arising when high fixed-cost investment must be sunk (Klein et al., 1978; Williamson, 1983). The different players generally face different price and quantity risks depending on their position on the supply chain and the technology used. LTC may then also enable them to allocate these risks to the party best able to manage it (Finon and Roques, 2008; Wiser et al., 2004). The pricing scheme and contract clauses should thus mirror the risk aversion profiles of the parties and the risk premiums will depend not only on the counterparties' characteristics and risk aversions but also on diverse political, regulatory and macroeconomic risks (Glachant and Hallack, 2009). Empirical research supports the theory and shows for instance that gas supply contracts linked to an assetspecific investment are on average four years longer (Neumann and von Hirschhausen, 2006; Stern, 1998). Similar relationships between transaction costs and the length of contracts had already been demonstrated by Joskow $(1985,1987 a, 1987 b)$ in the case of coal contracts. In the opposite direction, as soon as asset specificity decreases, efficiency gains attached to LTC tend to decrease as well (Doane and Spulber, 1994). Parsons (1989) for instance used an auction model to show that the strategic value of the gas sold by different producers in Russia, Canada and Norway through LTC diminished compared to the sale price on spot markets when the number of wholesale buyers increased.

It is important to note that LTC are not monolithic and display different results in terms of surplus and risk management depending on contract characteristics and the technology in- 
volved (Wiser et al., 2004). The inclusion of tacit renewal clauses for instance decreases the transaction costs of renegotiation (EDFIDEI Report, 2007). Reduction clauses allow the buyer to reduce off-take in case the supplier starts reselling in its commercial area, which protects the buyer's market and its sunk investments. Volume clauses may include rebate mechanisms which may reduce the price for the buyer. Exclusivity clauses also enable the buyer to decrease transaction costs. Indeed, Crocker and Masten (1988) and Masten and Crocker (1985) show that the take-or-pay clauses ${ }^{1}$ may provide enough flexibility to avoid breach and thus expensive renegotiation of contract. A LTC will thus be the most efficient governance structure for contracting parties if it ensures flexibility for renegotiation and solves the counterparty credibility problem (Borison and Hamm, 2005). In return, LTC will not be efficient for individual market players in all cases, especially if the economic agent has a certain monopoly or monopsony power and could manipulate spot prices.

\subsection{Efficiency for individual market players rejoins efficiency for the society in some cases}

Some positive effects of LTC on social welfare may thus clearly be depicted. In the short term, LTC tend to limit double marginalization (Onofri, 2005). Double marginalization occurs when several firms at different levels of the supply chain concurrently exercise market power and LTC, as vertical integration, allows the total single margin to be lower than the sum of the margin in the de-integrated case. LTC may also prevent abuse of dominance on spot markets, although this is a highly debated argument. The strategic behavior of firms on spot and forward markets has been the main stream of research in the economics of LTC in energy since the seminal contribution of Allaz and Vila (1993). The policy recommendations are not unanimous though. Due to the high concentration levels of supply and demand and the low demand elasticity, at least in the short term, abuses of market power on spot markets through e.g. withholding of capacities are likely. LTC may limit the incentives of dominant operators to abuse their market power on the spot as increases in prices would only be profitable on the un-contracted part of their supplies, hence LTC tend to increase traded volumes, especially when supplier concentration is low (Bushnell, 2007; Green, 1999; Willem and de Corte, 2008). This may however only be true if competition is modeled à la Cournot, especially if coupled with other measures to increase demand elasticity (Borenstein, 2002). By modeling competition à la Bertrand, Mahenc and Salanié, (2004) indeed show that price-setting producers with long position may sustain high prices by buying their own production forward. From a theoretical point of view, Bonasina et al. (2007) and Smeers (2009) however show that the set of assumptions used in the diverse models are too uncertain to firmly ground policy actions and order contract or asset divestiture. From a practical point of view, it will indeed be difficult for antitrust authorities to differentiate between the exercise of market power and legitimate scarcity rents (Fraser, 2003). It is also likely that the standard of proof used in courts would in any way be too high to use that argument.

The positive effects of LTC on social welfare are much more obvious in the longer term. First, LTC facilitate entry and thus contribute to market building if spot prices are volatile, when they

${ }^{1}$ Take-or-pay clauses give flexibility to the buyer by granting him the possibility to nominate the quantity of energy it wishes to purchase within minimum and a maximum contractual threshold. If the minimum quantity threshold is not reached, the buyer will have to pay for the shortfall at the full contractual price. For a lengthy description of the different take-or-pay clauses, see Coop (2006) are sufficiently long and when they can cover sufficiently high volumes (Green and Newbery, 1997; Newbery, 1998). The second positive effect is not only that it facilitates investment and thus contributes to long-term generation adequacy, it is also that it may contribute to fuel mix diversity by facilitating investment in base load technologies such as nuclear or coal (Finon and Perez, 2008). Indeed, the greater the fixed costs are, the greater are price and quantity risks (Finon and Roques, 2008; Roques et al., 2005). Whereas large, diversified and vertically-integrated incumbents can implement portfolio strategies and obtain a relatively greater value from base-load technologies (Roques et al., 2006; Roques et al., 2007), unstable spot markets constitute an especially high barrier to entry for new players in these technologies. Roques (2007) indeed shows that without LTC, CCGT is the preferred technology for new entrants as it is self-hedged given the correlation between electricity and gas prices observed in most markets. This makes CCGT particularly attractive to new entrants, which is confirmed by Watson (2004) in its comparative study between the CCGT and the fluidised bed boiler technologies. LTC might thus enable new entrants to invest directly in high-fixed cost technologies. This would also reduce their incentives to swap peak against base load capacities owned by incumbents, rather than investing, in order to reach a more balanced portfolio of technologies. A recent example of this was the agreement between EDF and POWEO signed in January 2007. POWEO gained access to EDF nuclear capacities from 2007 to 2021 and will give in return a future access to its CCGT currently in the construction phase, for the same capacity and the same period (160 MW per year over 15 years).

\subsection{But LTC can trap European energy markets in a vicious circle reinforcing the collective dominance of incumbents}

LTC have both positive and negative effects from the point of view of long-term social welfare. The main problem with LTC is the risk of foreclosure of more efficient players. This problem is even stronger in the new market context and is the main argument of the European Commission and national competition authorities to attack these contracts (DG COMP, 2007). If a significant part of demand is tied in the long run, a lack of retail outlets may lead to significant output foreclosure at the production level and tied consumers will not be able to subsequently benefit from future and potentially more profitable offers by new entrants. LTC may thus constitute a barrier to entry and have a negative effect on third parties. Conversely, if the market structure at the producer level is very concentrated, input foreclosure may occur and prevent entry in retail. For the Chicago School, an inefficient attempt to monopolize the market is impossible as it would require the acceptation of the buyer to incur the loss of not dealing with a more efficient entrant (Bork, 1993; Posner, 1976). This holds only under perfect information and if all possible parties are able to negotiate at the contracting stage. Under perfect information about the likelihood of entry of a more efficient supplier, economic theory shows that the current supplier is able to propose a contract with both a price and a penalty for default clause strictly advantageous for him but neutral or positive for the buyer. Rent would thus jointly be extracted by the incumbent and the buyer from the potential entrant but this would not impact social welfare. Therefore, under complete information, LTC could not be motivated by anticompetitive motives and would never be detrimental to welfare. An alternative explanation introduces buyer-to-buyer externalities while keeping the rationality hypothesis of the Chicago school. A buyer might agree to sign an inefficient LTC in order to reduce the size of a potential entrant's market, thereby reducing 
the probability of entry. As a result, other buyers will have to accept a higher price in the next period (Aghion and Bolton, 1987), which will give a competitive hedge to the first buyer. While it is rational to sign a LTC for a buyer in that case, buyer-to-buyer externalities render it negative for social welfare. Rasmusen et al. (1991) and Segal and Whinston (2000) introduce scale economies in production and multiple buyers to show that if an incumbent is able to secure a profit superior to the amount required to compensate the buyer from being tied, he will use LTC to fully foreclose the market. In case of competition between retailers, Fumagalli and Motta (2006) refined the analysis and showed that the risk of exclusion increases when the intensity of downstream competition decreases. Simpson and Wickelgren (2007) however argue that the opposite is true when buyers are allowed to breach exclusive contracts and pay expectation damages.

LTC also indirectly have exclusionary effects by drying out spot markets. Spot markets deliver better results than bilateral contracting only if sufficiently liquid. The absence of competitive spot markets is detrimental to social welfare in several ways. A competitive spot market allows more transparency than bilateral contracting on the evolution of supply and demand and the current production costs of the firms in place. The possibility to contract efficiently on the spot also limits the opportunity of dominant agents to abuse their market power when they contract bilaterally with smaller players. It mitigates as well the risk that in the long term LTC will lead to tacit collusion on spot markets by stabilizing the market shares of an oligopoly of collectively dominant suppliers (DG COMP, 2007; Le Coq, 2004; Liski and Montero, 2006; Neumann and von Hirschhausen, 2006). However, Green and Le Coq (2006) suggest that the longer LTC are, the lesser is the risk that collusion will be sustainable. The lack of a liquid spot market will not facilitate entry in retail and trading, and will thus foster volatility which encourages market players towards vertical re-integration or long-term contracting. Last, we note that similar exclusionary effects may also arise both from the fidelity rebates granted by dominant firms and from unclear termination rights, which provokes foreclosure effects and higher switching costs, thereby contradicting the current market building efforts of the EU.

Some contract clauses other than duration and exclusivity might also result in anti-competitive effects or express an attempt at monopolizing the market. Destination clauses and use restrictions hamper the integration of a single European market for energy, facilitate collusion between sellers and decrease competition intensity in the downstream market (Neuhoff and von Hirschhausen, 2006). Reduction clauses, the so-called 'English clauses', clauses of 'right of first refusal' or 'most favored customer' all have similar market partitioning effects. Clauses of tacit renewal, which typically decrease transaction costs for individual contracting parties, may easily have lock-in and thus foreclosure effects when the producer is overwhelmingly dominant.

At last, we note that, although not linked directly to the duration or exclusivity clauses, LTC might also entail severe price restraints such as excessive pricing or price discrimination. The price negotiated in a LTC depends on contracting parties' information about market conditions as well as on their respective bargaining power. As a result, an incumbent might well abuse the position of dependency of a new entrant or unfairly discriminate in favor of another incumbent. For instance, in case of regulated tariff in the downstream market associated with an overwhelmingly dominant producer upstream, a significant price squeeze may lead to severe barriers to entry. To the opposite, price discount linked to a long duration or a significant volume may distort competition in the downstream market if this rebate gives a competitive hedge to the downstream dominant firm.

\subsection{Conclusion: the EU actual antitrust dilemma with LTC in energy-} quo vadis European Commission?

This section has showed that the antitrust dilemma with LTC in energy is far from entirely solved by economic theory. The effect of LTC on welfare depend on many variables such as the different risks involved, the evolution of supply and demand, the storability of the product, market structure and primarily who is signing the contract. Economics does not provide any integrated model to weigh anti-competitive effects with potential efficiency gains over several periods of time but clearly shows the different elements to be taken into account to conduct the balancing exercise. The above analysis seems to indicate that building markets to increase welfare in deregulated energy markets might require an asymmetric application of antitrust policy, at least in the short term. Indeed, if a new entry may clearly depend on the signing of a LTC, the claim that potential efficiency gains counter-balance anticompetitive effects is much less clear in the case of superdominant incumbents which have already secured a wide customer base, even for investments in very high fixed-costs technologies such as nuclear.

A 'legalistic' analysis of LTC, especially if a pro-entry bias is favored, could lead to an analysis primarily based on the form of contracts and therefore to a general ban on LTC in energy. A more economic approach, to the opposite, could not rule out the fact that even dominant firms benefit from using LTC and that substantial foreclosure effects may not occur in every case. However, fully analyzing the pros and cons of all LTC would result in significant enforcement costs. The quality and efficiency of antitrust analysis largely depends on the level of information required to limit 'type I' and 'type II' errors in decision making. As a result, a constant preoccupation of antitrust policy should be to narrow down the number of cases where a full competition analysis is required to reach a decision. From that angle, the 'legalistic' approach would have the obvious advantage to clarify rules, both for enforcers and market players, and hence to facilitate self-enforcement through deterrence.

It is widely believed that the European Commission is taking a dogmatic approach on LTC and would simply consider them unacceptable when implemented by dominant companies. This can be understood as DG Competition since the early 2000s has publicly and repeatedly voiced strong concerns over the risks of anti-competitive effects inherent in energy LTC (Albers, 20012002; DG COMP, 2007) without clearly acknowledging their positive aspects. However, we will argue in the next two sections that if some uncertainty remains, a methodology of analysis has emerged at the European Commission and that this methodology takes into account most of the modern competition economics of LTC.

\section{A two-step methodology to analyze the anti-competitive effects of LTC in deregulated energy markets is emerging}

Prior to liberalization, LTC were not a priority of the European Commission which rather focused on removing legal monopolies over imports and exports. A few decisions in the early to mid 1990s nonetheless concerned long-term power purchase agreements between independent power producers and the national incumbents. They mainly aimed at limiting their durations so that these LTC would not jeopardize the forthcoming opening of markets. 15 years became the canonical duration accepted by competition authorities and no structured analysis of foreclosure effects was conducted. Since then, no clear methodology to analyze foreclosure effects in the context of deregulated energy markets has been clearly communicated by competition autho- 
rities and this is why legal uncertainty is so strong currently in the market place (Hauteclocque, 2009). However, since the early 2000s and especially for the last two years, a series of decisions have been taken concerning the portfolio of LTC of several incumbents (Repsol, E.ON Ruhrgas, RWE and most importantly Distrigaz) and new proceedings are regularly opened (EDF, Electrabel, GDF). We argue that a two-step methodology to analyze foreclosure of access to customers in the new liberalized context is emerging from recent decisions and that this methodology is clearly inspired by sound economic principles.

\subsection{Step one: market share thresholds and 'black-listed' contract clauses_per se prohibitions}

Antitrust enforcement is constrained by the rules contained in the EC Treaty as firms may appeal against the decisions of the European Commission before Community Courts. Art 81 EC which deals with anti-competitive practices and Art $82 \mathrm{EC}$ which tackles abuses of dominance, together with relevant guidelines, notices and regulation, do not a priori allow or ban LTC. They provide to the opposite a framework of analysis based on market share thresholds defining which situations must be fully investigated. This system is designed to provide predictability to the firms and allow competition authorities to focus their enforcement resources to the most serious infringements. It is thus based on the fundamental insight that vertical restrictions of competition may be harmful to competition only when horizontal competition is distorted. This means that the European Commission will act only when the LTC is implemented by a company with market power, market shares being used to approximate the level of dominance. This is an imperfect proxy for market power in many cases in energy but as concerns customer foreclosure, market shares seem a good and easy tool to use. To determine market shares and eventually ground the finding of dominance, competition authorities must first define relevant product and geographic markets. In both electricity and gas, the relevant product market is wholesale supply, by opposition to retail supply which excludes very large customers. The difficulties in defining the relevant product market in cases involving LTC have generally been similar in both industries and mainly reside in the definition of wholesale customers. Consumption level is generally the criteria retained but consumption patterns and demand profiles have also been used. An important issue is indeed whether large industrial customers (e.g. chemical and steel companies in electricity, CCGT in gas) and resellers constitute the same product market. Another issue is whether trading and supply markets should be dissociated, even though the European Commission has always considered power exchanges and hubs part of wholesale supply. As concerns the relevant geographic market, the European Commission has always estimated that relevant markets were national in scope, or even regional in certain downstream gas markets, primarily due to the presence of physical and contractual congestion on interconnectors. Relevant geographic markets may however be consistently moving in the new market context, for instance because of the development of regional exchanges and market coupling initiatives in electricity or a major structural reduction in long-term reservations of gas import capacity.

In practice, LTC between small and medium-sized companies are normally not considered by the European Commission as being capable of affecting appreciably trade between member states, except when they engage in cross-border trade. In fact, as long as the market shares of each contracting parties do not exceed 15\%, LTC do not fall under the jurisdiction of the European Commission. Beyond 15\% market shares, LTC are presumed to be legal so long as the market share threshold of $30 \%$ is not exceeded and duration is not indefinite or over 5 years. In case of collective dominance by several suppliers below the 30\% threshold, the European Commission or a national competition authority retains the right to conduct a full competition analysis. LTC for companies with larger market shares will require a full competition analysis in all cases.

To the system of market share thresholds has been added a list of black-listed contract clauses, called 'hard-core' restraints. These contract clauses are thought to contravene the fundamental Treaty objective of market integration and hence will almost never be accepted, which amounts to a quasi per se prohibition. Black-listed clauses relevant for energy are essentially market partitioning clauses, use restrictions and contractual provisions having similar effects. Forbidding market partitioning clauses and use restrictions makes sense for a homogenous product and in an industry that has traditionally been organized along national borders. During the course of recent decisions in energy, the European Commission has also made clear that clauses other than duration and exclusivity leading to significant switching costs would almost never be accepted when implemented by dominant firms. Among them, unclear termination rights, fidelity rebates and tacit renewal clauses have been considered illegal in several decisions. In these instances, the Commission has clearly favored the fight against foreclosure over the saving of transaction costs for individual contracting parties, even to the detriment of the non-dominant firms contracting with a dominant incumbent.

The EU law framework to analyze anti-competitive effects of LTC is thus primarily based on market share thresholds and a series of black-listed clauses. Even if these thresholds are set somewhat arbitrarily and have not been designed specifically for energy markets, they nevertheless contribute to ensure more predictability in enforcement. In addition, they rely on the fact that a firm with low market shares will not be able to distort competition sufficiently to justify a full competition analysis, which is justified from an economic point of view. As concerns the black listed clauses, it is obvious that the market integration objective played a big part in their definition. They however fit well in energy where the low level of market integration remains hard to overcome. Over 30\% market shares and provided that certain clauses are not included in the contract, competition authorities see a 'grey' area where the assessment of anticompetitive effects becomes more complicated and where, in theory, a multiplicity of elements should be taken into account. We will show that the emerging methodology of the European Commission evidences awareness of a lot of the modern economics of foreclosure.

\subsection{Step 2: analysis of anti-competitive effects in 'grey' cases-the relevant facts}

In case the LTC does not include any hard-core restraints and the market shares of at least one of the contracting parties exceed the $30 \%$ threshold, the European Commission will conduct a full competition analysis of the anti-competitive effects of the agreement to decide if it infringes EC antitrust law. This de facto limits antitrust enforcement in energy to the cases involving dominant incumbents. We will see in Section 3 that this is only when there is a strong presumption that the LTC will result in substantial anti-competitive effects that the analysis of potential efficiency gains attached to the LTC will be carried out and that a balancing exercised will be conducted. Long-term contracting by dominant firms is therefore far from being illegal per se.

Competition authorities will consider a lot of different elements to analyze anti-competitive effects. Some are purely intrinsic to the vertical relationship as the duration or the volume 
specified while others help analyze the market context, such as the level of vertical integration in the industry. This is reasonable in so far as the potential anti-competitive effects of a LTC, or a portfolio of LTC, cannot be understood without taking into account the specificities of the market context. We will thus first analyze how the European Commission assesses market characteristics before going on to its analyses of the contract itself.

\subsubsection{Analysis of market characteristics}

Market characteristics are usually what competition authorities analyze first. Economic theory is poor on insights regarding the patterns of entry in energy markets and the specific market features which favor it. In the recent line of decisions, elements taken into account included the maturity of demand, the level of vertical integration in the market, the real opportunity to set up a new resale network and the existence of buyer power. The latter is important as contracting parties frequently have diverging interests and thus incentives to contain each other's market power. In general, the European Commission considered that the presence of numerous buyers de facto limits the possibilities of abuse of a dominant position by the supplier. When assessing market characteristics, the European Commission also looks at potential entry in supply and demand, and its potential impact on future competition. This largely depended on the existence of potential competitors, usually foreign incumbents present in neighboring markets. A potential competitor is usually a firm able to undertake the required investments to enter the market within one year following a small but significant increase in prices as well as having a certain brand image and financial strength. For entry in electricity, ready available gas capacities have been considered an important factor.

The most important element will be the assessment of the cumulative effect of all the LTC signed by the different producers on market foreclosure. Indeed, LTC can foreclose markets to new entrants only to the extent that a substantial part of market demand is already tied for the long term. The doctrine of cumulative effect had been devised in a famous series of cases in the beer and ice-cream sectors and had been one of the cornerstones of the modernization of EC antitrust policy. As a general rule, the European Commission considers that a significant cumulative foreclosure effect is unlikely to arise if the total market demand tied in the long term does not exceed $30 \%$ of global demand. In the case of a 'super-dominant' incumbent like in the Distrigaz case, the European Commission considered that no competition concerns would arise if its portfolio of LTC would cover less than $20 \%$ of the market. In E.ON Ruhrgas, the Bundeskartellamt estimated that the firm contributed significantly to cumulative foreclosure with $75 \%$ market shares in its supply area, within a national market where $80 \%$ of total demand was supplied in the long term. This demonstrates that when a firm is largely dominant, the anti-competitive effects of its demand tied in the long term arise sooner. In the case of a group of leading suppliers, the European Commission will look similarly at the cumulative effects of their LTC but there will be no need to prove that they lead to tacit collusion to show that significant foreclosure effects occur (Kjolbye, 2007).

\subsubsection{Analysis of contract characteristics}

After having analyzed market conditions and their likely evolution, the focus will be on the characteristics of both the LTC itself and the contracting parties. Most prominently, the European Commission will conduct a combined analysis of duration, exclusivity and whether buyers who represent alone a substantial part of total market demand ('critical customer' concept) are tied for the long term with the dominant supplier, or the collectively dominant suppliers.

The European Commission will first look at the percentage of the consumer demand tied under the LTC, namely the exclusivity clause, as it is one of the main sources of foreclosure effect. Indeed, if a customer must meet all or a big part of its needs with a particular supplier for a long period of time, he does not constitute any longer an available outlet for a potential entrant. In Gas Natural/Endesa in 2000, the Commission reduced the size of the contract from nearly $100 \%$ to $75 \%$ of Endesa global purchases as Endesa was one of the leading electricity producers in Spain and thus could motivate entry in gas supply in its own right. More generally, the European Commission is looking here at the degree of economic dependency of the buyer vis-à-vis the dominant supplier. The share of the customer's demand tied is in the European Commission's view the best way to demonstrate dependency and it repeatedly used that proxy. Most importantly, the analysis of the European Commission is based on quantities actually received and not on quantities contracted. Indeed, takeor-pay or flexibility clauses are one of the main reasons why LTC dry out spot markets. Quantities effectively used are generally not the same than quantities previously forecasted and without flexibility mechanisms, buyers would be obliged to trade their surplus or source their missing quantities from spot markets. LTC could therefore contribute to the deepening of these markets while providing a fair level of supply security (Longva, 2008). Flexibility mechanisms are nevertheless not forbidden per se and the European Commission conducts its analysis on a case-by-case basis.

European competition authorities recognize when they analyze exclusivity that transaction costs may become too high when negotiating for a small quantity and that it may become uneconomic for an alternative supplier to provide less than a certain amount. Recent decisions seem to indicate that it is considered that $20 \%$ of a customer demand is the threshold for having incentives to enter into a relationship with a second supplier (E.ON Ruhrgas and RWE). Competition authorities are thus more reluctant to accept LTC accounting for more than $80 \%$ of a customer demand. Some commentators close to the European Commission think that foreclosure effects could be found for contracts amounting as low as $50 \%$ of a customer demand in case these contract terms are widely spread in the market (Nyssens and Schnichels, 2007).

The share of the customer's demand tied has to be analyzed along with the duration of the contract. Even if $100 \%$ of a customer demand is tied to a particular supplier, foreclosure will not occur if this customer can return to the market on a regular basis. As a general rule, the European Commission is very suspicious of contracts longer than 5 years and considers that efficiencies generally do not offset foreclosure effects beyond that limit. We also note that competition authorities consider contracts with tacit renewal clauses or no last delivery date as contracts of indefinite duration (E.ON Ruhrgas). Recent decisions show that the duration of contracts accepted by the European Commission will mainly depend on the competition position of the counterparty. If the counterparty is an established reseller, accepted duration will probably not exceed two years as in Distrigaz. The Bundeskartellamt in E.ON Ruhrgas restricted duration to four years for contracts with resellers who have more than $50 \%$ of their demand tied under the contract, but only two years above $80 \%$. European competition authorities will thus play with the two factors. Interestingly, where requirements are satisfied by several suppliers, the Bundeskartellamt specified that contracts should distribute the risk of demand fluctuations among suppliers according to the actual supply share provided by each of them so as not to disadvantage the smallest suppliers. In Repsol, 5 years duration 
was accepted for exclusive contracts with established resellers but the market shares of the dominant firm only reached $30-50 \%$, which shows that the European Commission adjusts duration according to the level of market dominance. For a new entrant in retail, duration of 5 years is most likely to be accepted. One also notices a more lenient approach of the European Commission towards fuel supply contracts than to electricity producer/reseller contracts.

\section{Balancing anti-competitive effects with efficiency gains and imposing remedies: the 'more economic' approach in EC antitrust policy and the 'pro-entry' strategy of the European Commission in energy}

Once the European Commission has considered that a LTC, or a portfolio of LTC, is likely to create significant anti-competitive effects, it will analyze the potential efficiency gains and proceeds to a balancing exercise. In case efficiency gains do not seem to clearly offset anti-competitive effects, LTC might still be accepted if satisfactory remedies can be imposed.

\subsection{LTC, efficiency gains and the practice of the balancing exercise}

The balancing exercise follows a methodology based on four criteria directly derived from the wording of the EC Treaty. In theory, for LTC with substantial anti-competitive effects to be cleared by competition authorities, they should (i) substantially improve economic efficiency, (ii) give a fair share of benefits to final consumers, (iii) be indispensable or at least proportional to the achievement of the efficiency gains and (iv) not afford contracting parties the possibility of eliminating competition in respect of a substantial part of the products in question. Objective factors out of the control of the company such as public service obligations may also be taken into account. In practice, we note that it is often difficult to trace back elements of competition authorities' decisions precisely to the four criteria.

The first criterion indicates that the LTC must create significant efficiency gains to be accepted. Recent decisions are however less clear on how to analyze efficiency gains than on how to assess anti-competitive effects. The outcome of the balancing will thus be even harder to predict. The two main efficiency gains recognized by the European Commission have been investment and entry. In Synergen for instance, the Commission accepted both a 15 years gas supply contract with Statoil for $100 \%$ of the needs of the new CCGT and a 15 years power purchase agreement for $50 \%$ of its output with the electricity incumbent ESB. It thus recognized the need of secure output levels and long-term upstream fuel commitments to facilitate investments and project financing. However, the mere objective of securing loans might not be sufficient to have a LTC accepted as the European Commission in other sectors did not always consider it indispensable. In case the loan comes from a dominant supplier, it is likely to be considered as an efficiency gain only if it cannot be obtained on the same terms with commercial or investment banks. It is also noticeable that the European Commission has once acknowledged that even dominant firms could claim for a certain level of security in fuel supply (Gas Natural/Endesa). The second criterion does not seem to have led to very substantial developments and in general was analyzed along with the first criterion on efficiency gains. As a general rule, the Commission considered that LTC helping investment and entry contributed to the success of the liberalization process, which was in itself thought to be good for final consumers.

The third (proportionality) and fourth (exclusion) criteria are obviously very difficult to implement and this is where the discretion as well as the difficulties of antitrust authorities really lie. European competition authorities are still struggling with them today. For instance, an open question concerns the duration that an incumbent electricity producer really needs to sink a very high fixed-cost investment (criterion 3 ) and how to make sure that this duration will not result in excessive exclusionary effects (criterion 4). A first indication was however given by the European Commission in the Exeltium case in September 2008. Exeltium was a consortium of energy intensive users to whom EDF was to supply base load electricity over more than 20 years. Alleged efficiency gains mainly included security of fuel supply and hedging for the buyers. The European Commission finally cleared this contract, after almost three years of analysis, provided that resale restrictions would be cancelled and an opt-out clause would be introduced to mitigate anti-competitive effects. In addition, the European Commission explicitly stated that the Exeltium agreement would be included in the analysis of the cumulative foreclosure effect of the contract portfolio of EDF currently being conducted.

Interestingly, one of the main advantage attached to LTC recently discussed in the economic literature, which is the potential mitigation effect of LTC on spot market abuses, has never been used by the European Commission. This probably reflects the fact that such economic analysis based on oligopoly modeling would not reach the legal standard of proof required before the court.

\subsection{Market building through antitrust remedies: the new treatment of incumbents}

In case efficiency gains do not seem to clearly offset anticompetitive effects during the balancing exercise, LTC might still be accepted if satisfactory remedies can be imposed.

A first group of remedies has consisted in modifying the drafting of contracts, for instance by deleting certain clauses such as use restrictions or limiting duration. In this case, the whole agreement is not cancelled and it belongs to the parties to decide whether the contract is still valid. Other more behavioral remedies have been imposed such as forbidding any vertical mergers or acquisitions for a certain number of years (Repsol). These are classical remedies in EC antitrust policy and are not specific to the energy sector. One notes here that if long-term generation adequacy is clearly a core policy goal of the European Commission, the vague concept of 'security of supply' is itself approached with more and more skepticism in antitrust cases. Today, even longterm gas import contracts are not sure to be accepted on the basis of a 'security of supply' argument, even though the series of cases involving dominant exporters evidenced the importance of international politics (Talus, 2007). From an economic point of view, the fact that the dominant supplier resides outside the EU does not change the potentially severe anti-competitive effects of LTC which can similarly be used to foreclose national markets. However, the antitrust practice of the European Commission on the long-term import gas contracts of Gazprom or Sonatrach with European firms has generally been more influenced by political considerations involving security of supply than by sound economic principles. The European Commission has indeed compromised the enforcement of EC competition law and limited its action to the deletion of 'black-listed' destination clauses, to the exclusion of any analysis of foreclosure effects. Longer durations (up to 25 years) were also accepted. We note that this status of exception was already accepted in the second gas Directive (2003/55/EC, Recital 25).

The second group of remedies has been specifically devised for the energy sector and coincided with the decision of the European 
Commission to use its power against abuses of dominance (Art 82 EC) to attack directly the portfolios of LTC of the incumbents. This was thought to be the only way to bring about rapidly substantial improvements in the competitive structure. The European Commission recognized that some of these LTC created real efficiency gains (criterion 1) but that the criterion on exclusion and proportionality could only be fulfilled if foreclosure effects were severely mitigated. This led the Commission to impose remedies better able to accommodate market players' needs while limiting foreclosure.

The Distrigaz decision constitutes according to the European Commission the landmark case for future antitrust enforcement on LTC in energy. The European Commission opened a proceeding against the Belgian gas incumbent for possible breaches of the EC Treaty rules on abuse of a dominant position due to their LTC with industrial customers. The European Commission started by excluding of the analysis of cumulative foreclosure effects all the LTC linked to a new investment in gas-fired power plants, in line with its analysis of efficiency gains. A strict limitation of 5 years was then imposed on remaining contracts to avoid that customers who would be particularly likely to switch suppliers be tied for a very long period of time and unilateral termination rights were granted to buyers with contracts longer than 5 years. A specific limitation to two years was imposed for contracts with resellers. The innovation lied in the flexibility parameters granted to the dominant firm. Distrigaz was allowed to adjust its portfolio of contracts to its own needs as long as it complied with contract durations of maximum 5 years and if $70 \%$ of its customers came back to the market every year. As a result, Distrigaz could indifferently have $37.5 \%$ of customers supplied under 5 year contracts and $62.5 \%$ supplied under one year contracts or $40 \%$ supplied under 4 year contracts and $60 \%$ supplied under one year contracts. These commitments were to last for a minimum of four years and until Distrigaz' market shares decrease below 40\% (or another supplier reaches the level of Distrigaz market shares minus 20\%).

\subsection{Conclusion: European LTC in competition policy-the European Commission is doing good, thank you}

The analysis of the recent series of decisions shows that the European Commission is using an economic approach to analyze foreclosure effects of LTC and imposing remedies in energy. Its combined analysis of duration, exclusivity and the pattern of consumption are particularly interesting. Even if the multiple-step methodology has not been devised for the specificities of newly deregulated energy markets, we have to conclude that this methodology balances favorably between the need for predictability and the need for a full competition analysis in complicated cases. True, the hierarchy among elements to be taken into account during the balancing exercise lacks of clarity and hence predictability. In addition, it is obvious that the analytical framework used and the remedies imposed are designed so as to be accepted by Community Courts in case of appeal. We can nonetheless already have a first picture of the emerging doctrine of European competition authorities on energy LTC.

\section{Conclusion}

The case of energy LTC is highly topical in the European Union. This paper has shown that the European Commission is much less dogmatic than is usually thought. Its analysis displays real efforts to both include recent insights of the competition analysis of foreclosure and limit regulation costs through a step-based approach. Even dominant incumbents are granted the right to sign LTC and the remedies imposed here and there have been innovative. However, the European Commission still takes a 'legalistic' approach in so far as its practice closely complies with what could be acceptable before the European Courts of Justice. In addition this new approach has not been devised for the specific context of energy market building and there is no reason to believe that the thresholds successfully used for beer and icecream are inevitably smart for energy. The market building efforts of the European Commission under its antitrust powers thus appear to be constrained by the procedural aspects of the legal process.

In addition, by building markets through antitrust, the European Commission necessarily focuses on market structure rather than on market design. This is a risky choice as our knowledge of competition dynamics in these sectors is too limited to propose very robust and efficient remedies. We must also note that building market through antitrust is far from being limited to the ex post tool kit. Antitrust has become a constantly on-going process of 'trial-and-error' which clarifies rules over time. Each rule being incrementally clarified then increases the credibility of self-enforcing competitive behaviors in the market.

\section{References}

Aghion, P., Bolton, P., 1987. Contracts as a barrier to entry. American Economic Review 77, 388-401.

Albers, M., 2001-2002. Energy liberalization and EC competition law. Fordham International Law Journal 25, 909-945.

Allaz, B., Vila, J-L., 1993. Cournot competition, forward markets and efficiency. Journal of Economic Theory 59 (1), 1-16.

Bonasina, M., Creti, A., Manca, F., 2007. Im-perfectly competitive contract markets for electricity. IEFE Working Paper.

Borenstein, S., 2002. The troubles with electricity markets: understanding the California's restructuring disaster. Journal of Economic Perspectives 16, 191-212.

Borison, A., Hamm, G., 2005. Better power contracts: using flexibility to increase value. The Electricity Journal 18 (10), 62-69.

Bork, R.H., 1993. The Antitrust Paradox: A Policy at War with Itself. Free Press, New York.

Bushnell, J., 2007. Oligopoly equilibria in electricity contract markets. Journal of Regulatory Economics 32, 225-245.

Chao, H., Oren, S., Wilson, R., 2008. Reevaluation of vertical integration and unbundling in restructured electricity markets. In: Sioshansi, P. (Ed.) Competitive Electricity Markets: Design, Implementation, and Performance, pp. 27-65 Elsevier Global Energy Policy and Economic Series.

Crocker, K.J., Masten, S.E., 1988. Mitigating contractual hazards: unilateral options and contract length. RAND Journal of Economics 19 (3), 327-343.

Coop, G., 2006. Long-term energy sale contracts and market liberalization in new EU member states-are they compatible?. International Energy Law and Taxation Review 2, 64-71.

DG COMP, 2007. Report on energy sector inquiry. SEC(2006) 1724, 232-244 283-294.

Doane, M.J., Spulber, D.F., 1994. Open access and the evolution of the US spot market for natural gas. Journal of Law and Economics 37 (2), 477-517.

EDF-IDEI Report, 2007. Contrat de Long Terme, Concurrence et Efficacité.

Ehlermann, C-D., 2000. The modernization of EC antitrust policy: a legal and cultural revolution. Common Market Law Review 37, 537-590.

Finon, D., Perez, Y., 2008. Vertical arrangements in decentralised electricity markets: a long-term efficiency perspective. LARSEN Working Paper.

Finon, D., Roques, F., 2008. Financing arrangements and industrial organization for new nuclear build in electricity markets. Competition and Regulation in Network Industries 9 (3), 247-281.

Fraser, P., 2003. Power Generation Investment in Electricity Markets. OECD/IEA Publication

Fumagalli, C., Motta, M., 2006. Exclusive dealing and entry, when buyers compete American Economic Review 96, 785-795.

Glachant, J-M., Hallack, M., 2009. Take or pay contract robustness: a three step story told by the Brazil-Bolivia gas case?. Energy Policy 37, 651-657.

Glachant, J-M., Lévêque, F. 2009. Electricity internal market in the European Union: what to do next?. In: Glachant, J-M., Lévêque, F. (Eds.), Electricity Reform in Europe: Towards a Single Energy Market. Edward Edgar, London.

Green, R., 1999. The electricity contract market in England and Wales. Journal of Industrial Economics XLVII (1), 107-124.

Green, R., Le Coq, C., 2006. The length of contracts and collusion. CSEM Working Paper 154, University of California Energy Institute.

Green, R., Newbery, D., 1997. Competition in the electricity industry in England and Wales. Oxford Review of Economic Policy 13 (1), 27-46. 
Gual, J., Hellwig, M., Perrot, A., Polo, M., Rey, P., Schmidt, K., Stembacka, R., 2005. Report for the DG Competition of the European Commission from the Economic Advisory Group on Competition Policy (EAGCP): An Economic Approach to Article 82

Hauteclocque, A., 2009. Legal uncertainty and competition policy in European deregulated electricity markets: the case of long-term exclusive supply contracts. World Competition 32 (1), 91-112.

Joskow, P., 1985. Vertical integration and long-term contracts: the case of coa burning electric generation plants. Journal of Law, Economics and Organization 1 (1), 33-80.

Joskow, P., 1987a. Asset specificity and the structure of vertical relationships. Journal of Law, Economics, and Organization 4 (1), 95-177.

Joskow, P., 1987b. Contract Duration and Relationship-specific Investments. American Economic Review 77, 168-185.

Klein, B., Crawford, R.G., Alchian, A.A., 1978. Vertical integration, appropriate rents, and the competitive contracting process. Journal of Law and Economics 28 (2), 297-326.

Kjolbye, L., 2007. Vertical agreements. In: 2nd Ed. In: Jones, C. (Ed.), EU Energy Law Volume II: EU Competition Law and Energy Markets. Claeys and Casteels, Leuven.

Lacy, B., 2006. Nuclear investment: performance and opportunity. Communication to the World Nuclear Association Annual Symposium 2006.

Le Coq, C., 2004. Long-term supply contracts and collusion in the electricity market. SSE/EFI Working Paper Series in Economics and Finance No. 552

Liski, M., Montero, J-P., 2006. Forward trading and collusion in oligopoly. Journal of Economic Theory 131 (1), 212-230.

Littlechild, S., 2005. Beesley Lecture.

Longva, P., 2008. Long-term contracting from the point of view of a big industrial energy consumer. Communication to the CESSA Conference, Florence.

Mahenc, P., Salanié, F., 2004. Softening competition through forward trading Journal of Economic Theory 116, 282-293.

Markiewicz, K., Rose, N., Wolfram, C., 2004. Has restructuring improved operating efficiency at us electricity generating plants? CSEM Working Paper 135, University of California Energy Institute.

Masten, S.E., Crocker, K.J., 1985. Efficient adaptation in long-term contracts: take-or-pay provisions for natural gas. American Economic Review 75 (5), 1083-1093.

Monti, M., 2003. Applying EU competition law to the newly liberalized energy markets. Communication to the World Forum on Energy Regulation, Rome.

Neuhoff, K., de Vries, L., 2004. Insufficient incentives for investment in electricity generations. Utilities Policy 12, 253-267.

Neuhoff, K., von Hirschhausen, C., 2006. Long-term vs. short-term contracts: a European perspective on natural gas. Working Paper CWPE 0539 and EPRG 05, University of Cambridge.

Neumann, A., von Hirschhausen, C., 2006. Long-term contracts and asset specificity revisited-an empirical analysis of producer-importer relations in the natural gas industry. EPRG Working Paper 0610, University of Cambridge.

Newbery, D., 1998. Competition, contracts and entry in the electricity spot market. RAND Journal of Economics 29, 726-749.

Newbery, D., 2006. The relationship between regulation and competition policy for network industries. EPRG Working Papers 0611, University of Cambridge.

Newbery, D., Pollitt, M., 1997. The restructuring and privatisation of the CEGB: was it worth it?. The Journal of Industrial Economics XLV, 269-303.

Newbery, D., van Damme, E., von der Fehr, N-H. M., 2003. Benelux market integration: market power concerns. Report of the Market Surveillance Committee, Dutch Competition Authorities.

Nyssens, F., Schnichels, H., 2007. Energy. In: Faull, J., Nikpay, A. (Eds.), The EC Law of Competition 2nd Ed. Oxford University Press, Oxford.
Onofri, L., 2005. Electricity market restructuring and energy contracts: a critical note on the EU commission's NEA decision. European Journal of Law and Economics 20, 71-85.

Parsons, J., 1989. Estimating the strategic value of long-term forward purchase contracts using auction models. Journal of Finance 44 (4), 981-1010.

Parsons, J., 2008. Fact \& fantasy: risk management in electricity markets. Communication to the EEM Conference, Lisbon.

Posner, R.A., 1976. Antitrust Law: An Economic Perspective. University of Chicago Press.

Rasmusen, E.B., Ramseyer, J.M., Wiley, J., 1991. Naked exclusion. American Economic Review 81, 1137-1145

Roques, F., 2007. Technology choices for new entrants in liberalized markets: the value of operating flexibility and contractual arrangements. EPRG0726 \& CWPE 0759, University of Cambridge.

Roques, F., Newbery, D., Nuttal, W., 2005. Investment incentives and electricity market design: the British experience. Review of Network Economics 4 (2), 93-128.

Roques, F., Newbery, D., Nuttall, W., 2007. Fuel mix diversification incentives in liberalized electricity markets: a mean-variance portfolio theory approach. Energy Economics 30 (4), 1831-1849.

Roques, F., Newbery, D., Nuttall, W., de Neufville, R., Connors, S., 2006. Nuclear power: a hedge against uncertain gas and carbon prices?. The Energy Journal 27 (4), 1-24.

Segal, I., Whinston, M.D., 2000. Naked exclusion: comment. American Economic Review 90, 296-309.

Simpson, J., Wickelgren, A.L., 2007. Naked exclusion, efficient breach, and downstream competition. American Economic Review 97 (4), 1305-1320.

Smeers, Y., 2009. How well can one measure market power in restructured electricity systems?. In: Glachant, J-M., Lévêque, F. (Eds.), Electricity Reform in Europe: Towards a Single Energy Market. Edward Edgar, London.

Stern, J., 1998. Competition and Liberalisation in European Gas Markets: A Diversity of Models. The Royal Institute of International Affairs, London.

Stern, J., 2004. UK gas security: time to get serious. Energy Policy 32 (17), 1967-1979.

Talus, K., 2007. Long-term gas agreements and security of supply-between law and politics. European Law Review 32 (4), 535-548.

Van den Bergh, R., 2002. The difficult reception of economic analysis in European competition law. In: Cucinotta, A., Pardolesi, R., Van den Bergh, R. (Eds.), Post Chicago Developments in Antitrust Law. Edward Elgar Publishing, pp. 34-59.

Verouden, V., 2003. Vertical agreements and article 81(1) EC: the evolving role of economic analysis. Antitrust Law Journal 71 (2), 525-576.

Watson, J., 2004. Selection environments, flexibility and the success of the gas turbine. Research Policy 33, 1065-1080.

Wesseling, R., 2000. The Modernization of EC Antitrust Law. Hart Publishing, Oxford.

Willem, B., de Corte, E., 2008. Market power mitigation by regulating contract portfolio risk. Energy Policy 36 (10), 3787-3796.

Williamson, O.E., 1975. Markets and Hierarchies: Analysis and Antitrust Implications. Free Press, New York.

Williamson, O.E., 1985. The Economic Institutions of Capitalism. Free Press, New York.

Williamson, O.E., 1983. Credible commitments: using hostages to support exchange. American Economic Review 73 (4), 519-540.

Wiser, R., Bachrach, D., Bolinger, M., Golove, W., 2004. Comparing the risk profiles of renewable and natural gas-fired electricity contracts. Renewable and Sustainable Energy Reviews 8 (4), 335-363. 